\title{
Educational Practices for Immigrant Children in Elementary Schools in Russia
}

\author{
Chulpan Gromova ${ }^{1, *}$, Rezeda Khairutdinova ${ }^{1}$, Dina Birman ${ }^{2}$ and Aydar Kalimullin ${ }^{1}$ \\ 1 Institute of Psychology and Education, Kazan Federal University, 420008 Kazan, Russia; \\ rezeda_raf@mail.ru (R.K.); kalimullin@yandex.ru (A.K.) \\ 2 School of Education and Human Development, University of Miami, Coral Gables, FL 33146, USA; \\ d.birman@miami.edu \\ * Correspondence: gromovajob@rambler.ru
}

Citation: Gromova, C.;

Khairutdinova, R.; Birman, D.;

Kalimullin, A. Educational Practices for Immigrant Children in

Elementary Schools in Russia. Educ Sci. 2021, 11, 325. https://doi.org/ 10.3390/educsci11070325

Academic Editors: Gerald Griggs, Elena Makarova and Wassilis Kassis

Received: 28 April 2021

Accepted: 23 June 2021

Published: 30 June 2021

Publisher's Note: MDPI stays neutral with regard to jurisdictional claims in published maps and institutional affiliations.

Copyright: (c) 2021 by the authors. Licensee MDPI, Basel, Switzerland. This article is an open access article distributed under the terms and conditions of the Creative Commons Attribution (CC BY) license (https:// creativecommons.org/licenses/by/ $4.0 /)$.
Abstract: Teachers have a pivotal role in the acculturation and adjustment of immigrant children. Practices are an important but an insufficiently explored part of teachers' work in a multicultural classroom. The purpose of the present research was to identify educational practices that elementary school teachers in the Republic of Tatarstan, Russia, use in their work with immigrant children to provide language and academic support and promote a welcoming atmosphere in the classroom that fosters psychological adjustment of the child. Data were collected through interviews with twenty elementary school teachers working with immigrant children. Interviews were analyzed using inductive and deductive content analysis methods. Findings suggest that in the absence of institutionalized structures, teachers take the initiative to adapt their teaching and instruction methods when working with immigrant children. Teachers primarily rely on individual (one-on-one) tutoring methods to provide language and academic support. Approaches to creating a favorable climate in the classroom and the child's psychological adjustment include practices of promoting respect for different ethnic groups and developing cross-cultural communication skills. Inclusion of parents in the educational process is used in conjunction with all practices with immigrant children used by teachers. In addition, teachers often rely on Tatar language as an intermediary between the migrant children's heritage language and Russian when communicating with them. Most children of immigrants are from Central Asian countries where the languages spoken are Turkic in origin and similar to Tatar-the indigenous language spoken in the Republic of Tatarstan.

Keywords: acculturation; adjustment; teachers' educational practices; immigrant children; language support; academic support; inclusion; welcoming school climate

\section{Introduction}

In the context of increasing globalization, migration, and resultant cultural diversity, the modern school plays an important role in addressing socio-cultural challenges faced by today's societies. The school is an important setting where acculturation and adjustment of immigrant children take place. In Russia, research and practice accounts suggest that schools are often poorly prepared to provide effective education to immigrant children [1,2].

Although migration to Russia is a relatively new phenomenon, Russia has one of the largest numbers of immigrants in the world. In 2017 it was the fourth largest destination country after the United States, Germany, and Saudi Arabia [3]. According to the Russian Ministry of Internal Affairs [4] the number of registered immigrants in Russia was 6,993,602 people in June 2018.

The largest migration flows into Russia are from Uzbekistan $(3,446,849)$, Tajikistan $(1,745,554)$, China $(1,437,891)$, Ukraine $(1,319,051)$, Kyrgyzstan $(620,417)$, Kazakhstan $(502,420)$, Azerbaijan $(490,265)$, and Armenia $(490,168)$. However, there are few statistical data regarding immigrant children in Russia. According to Russia's Committee for Education [5], immigrant students are concentrated in smaller schools (not more than 
400 students), while they comprise no more than $5 \%$ of students in larger schools. In a significant number of Russian schools, there are no immigrant children at all [1] (p. 15).

In accordance with Russian legislation, immigrant children are entitled to receive an education in any school in Russia. Chapter 1, Article 5 of the law on Education in the Russian Federation (2013) states:

1. There is a guaranteed right to education for every person in the Russian Federation.

2. The right to education in the Russian Federation is guaranteed regardless of sex, race, nationality, language, origin, property, social and official status, place of residence, religion, beliefs, membership in public groups or any other circumstances [6].

However, the right to education applies only to legal residents. Foreign children are allowed to attend educational institutions in Russia only if they hold a residence permit [7]. According to the Russian Education Fund, about $80 \%$ of immigrant children do not attend kindergarten due to reluctance to register and a shortage of places [5]. Also, according to the same source, in 2014 every third immigrant child did not have access to education, an increase from 2011 when only every tenth child did not have that opportunity [5].

The presence of even a few first-generation immigrant children in school requires the provision of special supports and teaching approaches. Such approaches to developing a favorable environment for integration of immigrant children are referred to as multicultural, intercultural, or polycultural education [8-10]. Some scholars have described important differences between these approaches. In the United States some refer to intercultural education as teaching and learning about different cultures [11], whereas multicultural education is described as a political movement that stems from the U.S. Civil Rights Movement and aims to address inequities in education from a structural perspective [12]. However, Russia (and the USSR before it) has its own extensive history with respect to educating students from diverse ethnic backgrounds. Valeeva and Valeeva (2016) use the term intercultural to describe these approaches in Russia and note their focus on intercultural communication, promoting tolerance and respect for different cultures, and teaching different languages, histories, and geographies for the purpose of "the enrichment of representatives of all cultural groups" [13] (p. 1569). While there are important differences, all of these approaches aim to foster mutual respect, understanding, and tolerance toward others [14-16].

Regardless of terminology and conceptual differences in approaches in different countries, teachers play a key role in integration of immigrant children in schools. Studies find that teachers are responsible not only for education but also for acculturation and developmental processes of immigrant children in schools [17-19].

Teaching practice, or pedagogy, has been defined as both an art of being a teacher, and a science of teaching. It generally includes strategies, styles, the context of instruction, and teachers' actions in the classroom [20]. Specific practices used for teaching immigrant children are closely related to addressing issues of acculturation. Previous studies elaborate on difficulties that immigrant children face in a new culture. These difficulties are related to learning a new language, a new culture, coping with migration trauma, adjusting to different school requirements, and academic standards in schools [21-25].

Educational practices used with immigrant children can be studied on the institutional, personal, and instructional levels $[15,26]$. Institutional level practices are implemented at the level of the whole school. Personal level practices include teachers' actions as a culturally responsive person. Instructional level includes teaching strategies and methods. While teachers do not directly influence educational policies, they are proactively involved in the educational process with immigrant children on all of these levels.

Dumcius et al. (2012) describe five models of educational support provided in different European countries: (1) non-systematic support, where the state does not adopt any systematic policies regarding education of immigrant children, leaving schools and teachers to initiate their own approaches; (2) compensatory support, that aims to help students catch up academically through teaching the host country language and providing interpretation services to parents; (3) an integration model where linguistic support stops after a few 
years, no mother tongue teaching is provided, and intercultural learning is integrated into the curriculum; (4) a centralized entry support model where assessment and welcoming arrangements are centralized and linguistic and academic support are well developed; and (5) comprehensive support models that provide all four types of support. These support models differ from each other in who is responsible (national educational system or the local school) and in the extent to which they address four aims: linguistic support, academic support, parental and community involvement, and intercultural education, which is defined as ensuring a positive environment at school [27].

In the literature on school support for immigrant students, the first and most important aim is learning a new culture, which primarily involves learning a new language. Christensen and Stanat (2007) describe five types of language support provided to migrant children in different countries: (1) immersion-immigrant students are not provided with any language support and study in regular classes; (2) immersion with systematic support-immigrant students study in a regular class but they are provided with language support for a certain period of time; (3) immersion with a preparatory phase-immigrant students attend preparation courses before joining a regular class; (4) transitional bilingualimmigrant children study in their native language before gradually moving to study in the language of the host country; and (5) maintenance bilingual-immigrant children learn in their native language as well as the language of the host country [28].

The bilingual approach, when students develop native language skills along with host country language skills, is considered to be effective [29-31]. However, as Christnsen and Stanat (2007) note, providing bilingual education may be unrealistic in some countries. They suggest that immersion with systematic language support or a preparatory phase may be effective practices [28]. Others have described specific approaches to teaching the language of the host country including speaking, writing, teamwork and discussions [32,33]. Here, teaching a host country language as a second language is considered to be the most successful strategy compared to traditional teaching methods used with native speakers [33-36].

The second aim of teachers' work is academic support, which is directed at reducing academic gaps. This is very important for immigrant children as without knowledge of the language of instruction they fall behind at school [37]. Insufficient knowledge of the language may occur not only in the first but also in the second generation of immigrants [28].

Third, research underscores the importance of promoting trusting relationships in the classroom so that immigrant children feel comfortable and included [38]. This means building good communication and collaboration in a class $[39,40]$. These three foci of teachers' work with immigrant students are explored in the present study.

\section{Purpose of the Study}

This research is based on Vygotsky's sociocultural theory, which considers learning and development as a culturally, historically, and socially mediated process [41]. The leading role in the child's education and development belongs to the adult- the teacher. Applying this theory to multicultural education, the teacher should possess the knowledge and practices to implement multicultural programs [42]. Multicultural practices are defined as collaborative actions of teachers and students [43].

The need for this study arose because of the lack of research about teachers' experiences in multicultural classrooms in Russia. Meanwhile, there is also the need for qualitative descriptive studies, which deepen understanding of how schoolteachers solve problems of integration of immigrant children [44,45]. In our previous quantitative study, we also concluded that qualitative research is needed to better understand the methods teachers use to teach immigrant children [37]. The aim of the present study is to identify and describe educational practices elementary school teachers in Tatarstan use with firstgeneration immigrant children. These children were brought to Tatarstan by their parents and came from Uzbekistan, Tajikistan, Azerbaijan, and other countries. Our study focuses on understanding how educators solve problems of integration of immigrant children 
in Russia's schools. The study is intended to contribute to the literature on educational practices used by teachers when working with immigrant students.

\section{Materials and Methods}

The study used an interpretive research paradigm and an exploratory qualitative design to describe teacher practices $[40,46,47]$.

\subsection{Setting and Participants}

Participants of the study were teachers from different cities in Tatarstan. Tatarstan is an ethnically and religiously diverse region in Central Russia. According to the 2010 census, over 173 different ethnic groups live in the region. The eight largest groups (more than 10,000 people) are Tatars, ethnic Russians, Chuvash, Udmurts, Monrovians, Mari, Ukrainians, and Bashkir. The majority of the population in Tatarstan are Tatars, who are historically Muslim, and ethnic Russians, who are historically Orthodox Christians. Tatarstan has the sixth largest number of immigrants among Russia's regions. The overall number of registered immigrants in Tatarstan is 126,360 people, with the largest group being migrant laborers $(36,631)$. As there are no statistical data on immigrant children, we asked teachers in the study about the number of immigrant children in their schools and classrooms.

Twenty elementary school teachers with experience of working with immigrant children agreed to take part in the study (see Table 1). We engaged in purposive sampling [46], selecting teachers in Tatarstan of any ethnicity who had experience working with immigrant students. Since no statistical information is available on enrollment of immigrant students in particular schools, we relied on local knowledge. Twelve teachers were recruited from professional development courses, which are mandatory every five years for all teachers in Russia. The courses were held in Kazan, with teachers from different cities in Tatarstan attending. During these courses teachers were invited to participate if they fit our inclusion criteria. Eight teachers were recruited from schools known to the researchers to have a large number of immigrant children. This information came from student teachers who were placed in these schools for their internships.

Table 1. Demographic information about the participants.

\begin{tabular}{cccc}
\hline Age (Average/Range) & Experience (Average/Range) & Sex (Female/Male) & Place of Residence (Kazan/Other) \\
\hline $46.26 / 31-56$ years & $21.71 / 0.5-34$ years & $19 / 1$ & $16 / 4$ \\
\hline
\end{tabular}

As shown in Table 1, participants had worked in elementary schools for an average of 22 years. All but one teacher were female. Ethnically, ten participants were Tatar, eight Russian, and one was Mordovian. In addition, one teacher had personal immigration experience as an immigrant from Kazakhstan. The majority of the teachers lived and worked in Kazan.

\subsection{Data Collection and Analysis}

Data were collected through individual semi-structured interviews from December 2017 to June 2018. We initially asked whether teachers had any experience working with immigrant children. If they had such experience, we continued with the interview. Participants gave their consent to be interviewed and to have the interview recorded. They were assured that personal information (name, place of work) would be kept confidential.

To avoid leading the interviewees and impose researcher's views, and to reduce social desirability, participants were not fully informed about the specific focus of the research on teacher practices. As teachers often think that the quality of their work is being evaluated, we were concerned that they may report using teaching practices that they do not actually use. Rather, the aim of the interview was described in more general terms to learn about immigrant students in schools. The interview was prefaced with the researcher's statement: 
"We highly value your practical experience. It is very important to know the opinion of an experienced teacher about the difficulties you encounter when working with immigrant children. Please tell us about your experience of working with immigrant children". After teachers described where the children migrated from and what difficulties they faced, the interviewer asked them to describe how they worked with the children and solved problems. During interviews the teachers were encouraged to express themselves freely. However, the interviewer kept in mind the research questions, asking about topics listed in the interview guide. For example, if the teacher did not address a particular topic, the interviewer asked questions about it such as: "how do you help the student with learning the language?" To elicit more specifics, the interviewer asked follow-up questions such as "which problems in school do they face most often?" The teachers willingly talked about the children they work with, how they work with them, and what difficulties they experience.

The interviews lasted from 45 to $90 \mathrm{~min}$ and were subsequently transcribed. The transcripts were read several times to get a general sense of the participants' feelings and perceptions, and discussed by the research team. In every transcript we identified quotations that had certain practice-related phrases or statements and highlighted them with a marker. In all, we identified 180 quotations and sorted them into categories as described below.

The quotes were analyzed deductively and inductively. All codes were reviewed by members of the research team who reached consensus about the final categories. The deductive approach was based on the classification of practices/supports suggested by Dumcius et al. (2012): linguistic support, academic support, parental inclusion, and intercultural education and positive school climate [27]. We decided not to use "parental inclusion" as a separate category because during the coding process we realized that working with parents was done in the service of all other practices, including language support, academic support, and creating a positive school climate. Through an inductive approach we identified specific practices that teachers use in their work in the service of these aims.

\section{Results}

\subsection{Language Support}

In 75 quotations, teachers talked about methods for teaching the Russian language and improving children's language skills. Only one teacher mentioned that their school organizes special Russian courses for immigrant children. All other teachers reported that language support is provided individually as additional help by themselves or by outside tutors. For example, these teachers describe how language support is provided during after-school activities:

Interview 16: "We stayed after the class. I explained what she didn't understand in words and using gestures. During the after-class activities we repeated everything we learned in class, in every subject. I explained all the topics again. We wrote dictations, keywords, small essays. Sometimes parents hire a tutor for additional classes".

Interview 14: "The tutor is concerned with the main [Russian] language; they mostly try to identify the knowledge gap and work on it. They read the tasks; try to understand what the student didn't get".

One teacher (Interview 16) said that such an approach is effective in this quote: "And this kind of individual work produced results".

Teachers also mentioned that children learn the language faster through daily communication and TV than they do in school:

Interview 6: "I had one who didn't know the language. He spent a whole year in pre-school, we both struggled; he didn't know anything at all. His brother sat with him, explained and showed him; he cried. And during the summer, just in three months, he 
learned to talk. He spent the whole summer on the street with kids and after that he started talking. He understood what we talked about".

As for the content of additional lessons, teachers mostly said that they work with immigrant children on study materials orally and in writing. Students read, retell, and learn rhymes by heart. Work on literary texts includes explaining the meaning of unknown words, picking synonyms for words, especially proverbs and sayings so that the child would not just read, but also understand what they are reading:

Interview 12: "We work on texts during after-class hours, reading. We ask them to retell in order to develop their speech ... We write dictations because it helps to remember".

Interview 15: "I had to explain some words, mostly when we worked on vocabulary. Sometimes I have to explain Russian proverbs and sayings, of course, this is during individual work".

Interview 14: "Right now we are working only on dialogues, so he could communicate and express his ideas".

Among communicative language training techniques, teachers most often singled out communication with peers and teachers. Many teachers pointed out that children learned the language faster through communication and games. Their vocabulary grew because they learned new words and repeated after their peers. Hence, many educators tried to create conditions for children to communicate more during after-school activities, school camps, additional classes, stage plays, and social clubs as described by this teacher in Interview 14: "I organized group work so that they could talk more and help each other. Then, a preschool camp ... to communicate with children and teachers".

Teachers also asked other immigrant children to help those who struggle with the language. This teacher explained (Interview 8): "The kids who more or less understand Russian try to translate. They explain through gestures, pictures, put it in simpler words".

Meanwhile, Tatar language knowledge helped teachers communicate with and explain to immigrant children whose knowledge of Russian is poor. Tatar language belongs to the Turkic language group, so it is similar to the native languages of children from Uzbekistan, Kyrgyzstan, Kazakhstan, and Azerbaijan. These teachers explained:

Interview 19: "They can communicate through the Tatar language. Through Tatar language teachers communicate easier with them, they also translate what we don't understand. The Turkic languages are similar".

Interview 5: "Tatars and other pupils compare similar words in the classroom, it's interesting. There are similar words in the Kazakh and Uzbek languages".

Interview 17: "No, they're the same Russian language teachers but they're ethnic Tatars and know Tatar well. And it's simpler for them to communicate with these students because they speak mostly Turkic languages. So, they are teaching Russian through Tatar".

Only one teacher stated that their school provides immigrant children with special Russian language courses. Many other teachers believed such courses should exist, but they did not specify what should be taught or which teaching methods should be used. One teacher commented (Interview 15): "More focus on the Russian language [is needed]. They won't learn the material without knowing Russian. Of course, we have the after-school [Russian language] class but it's for everyone. We need a special one for these children". Only one teacher mentioned that a particular teaching method would be the most appropriate- - teaching Russian as a foreign language.

Teachers attributed children's poor language skills mostly to low language skills of their parents. As a result, we focused some analyses on identifying language teaching practices that involve parents. Teachers talked about the need to work with parents, to explain to parents that they needed to convince their children of the necessity to learn the Russian language even if that meant placing the child in a lower grade. For example, in 
response to the question "what should be done to teach children the Russian language?" these teachers said:

Interview 12: "I don't even know. Knowing the [Russian] language so parents can explain to the child. Talking to parents that it's necessary to study, that they also should put in some effort".

Interview 4: "And I think that if an immigrant comes to school, we shouldn't put them in a grade according to their age, maybe to a lower grade, but you have to explain this to parents".

In one interview the teacher said that a parent came to class herself to learn the language (Interview 5): "The child's mom brought a translator with her and studied in the back of the class". In other cases, teachers recommended Russian language courses to parents, as in Interview 12: "Maybe [it's necessary to] teach parents, maybe after-class courses for parents, so parents can attend them with kids".

\subsection{Academic Support}

Academic support refers to teaching practices designed to improve or support children's academic performance (36 quotes). As with language support, teachers worked with children individually or suggested that parents hire tutors. Teachers provided additional explanations and lessons after school or during vacations.

Interview 3: "We explain it to someone individually. I can't do it when the whole class is present".

Interview 4: "Yes, [I provide] additional explanation after classes, but sometimes they stay in the after-school clubs. They study there".

Interview 19: "We do homework with them during the after-school hours, I help them. Next day it's like starting from a scratch. As our psychologist said, "don't be lazy". And it goes on and on day after day".

Interview 18: "When I don't have a preschool camp, I invite them during summer and winter holidays for 2-3 hours".

However, two teachers said that additional classes and tasks are not necessary in Interview 2: "There is no need to give them additional tasks" and Interview 6: "It is pointless to keep them after classes". Some students had outside tutors who helped them with schoolwork, as explained in Interview 12: "But some girls now have tutors, twice a week, they do homework with them".

During class teachers explained the material in a simplified way, through visual aids, examples, actions or repeated the same material if needed. For example:

Interview 9: "While explaining the topic I used graphics because children remember things better visually. They won't understand everything orally. If, let's say, it's related to math. One time a child didn't know the multiplication table. We did operations with numbers ... All children understand numbers; they're the same in all languages. So, I used graphics".

Interview 11: "I pulled out my wallet and the coins, we added like that. They understood with coins, but on the blackboard-no way".

Interview 8: "I have to explain it on fingers and with pictures".

In some cases, teachers were able to explain only with the help of another child who acted as a mediator. A peer mediator could be an immigrant or a non-immigrant child, who could explain the academic material using simpler language. For example:

Interview 9: "I asked other children to explain, to try to explain it. Children understand each other better. They talk differently, not using smart phrases like us. I asked classmates to explain it to them on their own". 
Interview 6: "I try to put well-performing and poorly performing students in pairs, because children can explain to each other better".

Interview 19: "When children got older, in third - fourth grades I started using the help of assistants. Assistants are well-performing classmates. And well-performing immigrant children also became assistants, they helped too".

Teachers also engaged parents to improve students' academic performance. Teachers explained to parents that it is important for their children to study; and explained teaching materials so parents can explain them to their children.

Interview 10: "If I call him [parent], he comes, and I explain. The dad would often make a brief visit after the work".

Interview 16: "And then I gave advice to the parents on how to work with children at home. I called them every day and explained everything. What we do in class, what we do after class and what should be improved at home".

Interview 9: "I talked about the importance of education at the teacher-parent meeting".

Children worked on their homework with parents. At the same time some parents were not able to help their children with homework because of poor Russian language skills or low educational level.

Teachers also tried to use an individualized approach with children, adapting tasks according to the child's abilities. For example:

Interview 18: "I almost never give them tricky tasks as homework, except maybe the simplest ones. It would be better at least if they could cope with the basic part of the curriculum. Simplified homework... For example, if Russians have to retell the whole text, I give them only a part of it".

Interview 2: "If I'm asking to recite a poem, I do not ask them on that day. I know it will be difficult for them".

Teachers also adjusted their grading with immigrant students and gave them better grades if they saw a benefit in doing so. Usually, teachers did this to encourage and motivate the children. For example:

Interview 18: "But I also tried to give better marks to motivate the child. I used to give 4 's for a dictation [equivalent of a B letter grade], even if there were 40 mistakes. I invented my own mark, pointed out typical mistakes and grouped them".

Interview 3: "But we make some excuses for them, of course. It's a must. If we give someone else a 3 [equivalent of a $C$ letter grade] for that number of mistakes, we can give a 4 here. It's an encouragement".

One teacher just gave students a 3 [equivalent to a C] regardless of children's effort and improvement (Interview 4): “Yeah, I'm just giving them 3's. In Math, Tatar, and English they deserve it but in Russian-no".

\subsection{Promoting a Positive School Climate to Foster the Child's Psychological Adjustment in the Classroom}

To create a positive and welcoming climate at school, teachers described teaching respect toward different ethnicities and developing cross-cultural communication skills (69 quotations). These practices sometimes coincided. For example, one teacher reported that she initiated a special club where children of different ethnicities can communicate. The teacher invited children of different nationalities, including immigrants, to join a club to create a positive intercultural climate:

Interview 5: "Our school has a social club called "Friendly Family". It's my personal initiative. A community organization [outside the school] provides additional money. Children of different nationalities join the club. We get together once a month or once 
a week. We discuss world news, or we have kids who come up with something in their language and tell us. We try to attract kids who don't speak [Russian] well, too".

In addition, teachers employed practices for promoting a generally positive socialpsychological climate in the classroom, not specific to issues of cultural diversity. For example:

Interview 14: "I put children in contact with each other so they could talk more and help each other".

Interview 19: "And we give them tasks. For example, we ask them to give out notebooks, collect notebooks. It may be a small task but it's still communication. I do everything to get them involved".

To teach respect toward different ethnicities and create a culture of international communication, schools organized national celebrations. These festivals give immigrant children opportunities to recite poems, dance their national dances, sing national songs, and serve national dishes. For example:

Interview 19: "Four times a year we organize a festival of different peoples where immigrant children represent their countries. Such events improve attitudes toward them. They wear their national costumes, read and sing in their languages, perform national dances".

Interview 5: "I held an annual festival called 'Me, you, he and she are a friendly family'. We prepared for it for a year. I invited a Tajik boy who recited a poem, and a Tajik girl who danced in a long dress. There were an Uzbek girl and a boy. They performed an Azerbaijanian dance. There were national dishes of all sorts. A Georgian girl performed a Georgian dance, it was very melodic. We served the food and let everyone try".

Parents were also involved in the process of intercultural dialogue. For example, one teacher mentioned that native and immigrant parents taught children different cuisines, traditions, and customs. One teacher said:

Interview 5: "We visited a Russian family during Easter, painted eggs and recorded it in on a camera. They told us about the origins of that holiday. Once an Azerbaijanian mom came and taught children how to make cookies. She brought the dough and explained how it's served".

In two interviews, teachers talked about the help that ethnic Diasporas in Kazan provide in teaching children about different cultures. They also helped resolve conflicts.

Interview 5: "They have Sunday schools [in the Center of Ethnic Friendship]. They gather there, many attend it. We have relationships with them, and they always invite me with the children. I can take any class and go there. Uzbeks, Ukrainians, Azerbaijanis. They perform at festivals, organize workshops and open classes. Sometimes they visit us, too".

Interview 17: "Our school works together with the Center of Ethnic Friendship. We know each other and work with leaders of all Diasporas. Together we solve conflicts that could arise with some children's parents".

Teachers held discussions with entire classes as well as with the immigrant children as another practice in the service of developing a positive climate. Discussions with the entire class were done to prevent discrimination against immigrant children.

Interview 3: "I never allow children to bully kids of different ethnicities".

Interview 20: "A boy [name], he's slightly darker than other kids ... He was insulted".

Interviewer: "What did you do with this?"

Teacher: "I discussed it during the class meetings. I had very few kids. It is convenient. It was in Tatar language class". 
Teachers explained to all children that they should help and support each other.

Interview 8: "Of course, we tell children to support each other, so other children could help him, make friends, communicate so he could help you, so you can collaborate. And children are trying to support them. I let them know that they should support him".

Teachers explain the principles of mutual respect and intercultural communication.

Interview 19: "It's all different for everyone. From the very first grade I explain to children and their parents that we all should live in friendship and agreement regardless of what nationality you are. I support tolerance and encourage our kids. I explain how hard it can be for migrant children".

Teachers held individual talks with immigrant children to address their aggressive behavior, explaining to them that they should be friendlier. For example, in Interview 19 the teacher said: "I explain to them that they shouldn't get upset. Of course, it's difficult". Conflicts were also a reason to have discussions. In one interview the teacher said that she talked not only to students but also to parents to solve a conflict between children.

Interview 13: "Well, we talked, solved these conflicts. I called the parents, talked to the dads and the boys. We talked so they could feel comfortable in the classroom, to change their opinions somehow. The dads sat across from each other, Azerbaijanian and Tatar. I told them that if we can't find common ground between them, it would be impossible for their kids to study together".

Only in one interview (Interview 16) a teacher mentioned the help provided by a school psychologist when a child experienced problems communicating with other children: "Well, we have a psychologist. She came up in the first class when one girl had problems with other children ... She worked with her individually". Teachers lamented a lack of such specialists who could help them in schools, as in Interview 6: "There should be a school psychologist. There should be specialists in a school".

\section{Discussion and Conclusions}

Our study findings are that teachers in Russia had to use additional individual lessons with immigrant children to teach them Russian and help them improve their academic performance. On the one hand, this is similar to what happens in other countries without centralized models of transitional practices for immigrants [27,48]. On the other hand, giving immigrant students one-on-one attention is considered a very effective practice to help newcomer children adapt to a new school $[31,38]$. During additional lessons, teachers in our study explained academic material one more time or worked with texts, though without using special methods for teaching Russian as a foreign language. This is despite the fact that special instructional methods for teaching Russian as a second language have been developed by Russian educators [34,35,49-51]. Similar to Gorpas (2011), teachers in our study believed in the necessity of teaching Russian language to students, but only one of them was even aware of methods for teaching Russian as a foreign language [48]. Some teachers admitted that they need to learn about teaching methods, special books, and guidelines for teaching immigrant students. These finding underscore the need for teacher education programs to include training on teaching culturally diverse and multilingual students in todays' increasingly diverse classrooms.

One individualized approach with immigrant children is when teachers give them easier assignments and use different grading criteria. Teachers in our study tried to support children's tiniest achievements by giving them more accessible tasks, tailored to their abilities. Previous studies have also suggested the importance of initial assessment and monitoring of the child's progress [31,37]. On one hand, some researchers consider such practices to reflect low expectations, which lead to low performance [52,53]. On the other, immigrant children cannot cope with difficult assignments when their knowledge of the language of instruction is poor. Our research also suggests the necessity of developing and implementing initial assessments to determine the level of students' knowledge and skills 
when they enter the school. This would assist teachers in developing appropriate practices for incoming students. Monitoring students' achievements and academic progress at the state level can avoid grade inflation and manage teachers' low expectations. This presents an additional challenge for schoolteachers.

The role of the mediator between newly arrived immigrant children and their parents and the school was played by children and teachers who knew the Tatar language. This finding supports results of previous studies that found teaching a new language with the support of the native language to be one of most effective strategies. While the Tatar language is not native to immigrant children, it is closely related to the native language of many Turkic peoples who move to Russia and Tatarstan. As in prior research, without formal language support, teachers in our study relied on assistants [37], mentors [14,54], or translators who are usually other immigrant children $[37,55]$. This teaching practice aids communication between peers and teachers and can help prevent segregation from a Russian-speaking environment $[14,37,45]$. In our study, teachers reported asking peers to speak Russian to the students not only to help them learn the language but also to explain lesson material in plain language. This method is an important part of cooperative learning and translanguaging $[30,56]$. However, it was hard to discern from our interviews whether teachers used this measure intentionally or were forced to do so without institutional support, as all support provided to migrant children stemmed from the teachers' personal initiative.

With respect to ways of promoting positive climate in the classroom to foster psychological comfort for children, our study findings resonate with two approaches recommended in schools with immigrant students. The first is creating an environment that encourages communication among children and the second is promoting respect for cultural diversity $[55,57,58]$. Although learning about different cultures in school has been criticized as "touristic" [59] (p. 57), nonetheless, all children benefit from learning more about their own and other cultures [15,60-62]. As described in prior research, teachers in our study described holding discussions with immigrant children and other students to reduce tensions, solve conflicts and encourage collaboration with parents [63]. In addition to previous studies, we found that relying on ethnic diasporas may be good practice to aid in acculturation of immigrant children and solving conflicts with their parents.

The main finding in our study was that without systematic, centralized support [64] or specialized training, teachers had to take the initiative and create personalized approaches when working with immigrant children. Although the data were initially analyzed deductively based on the literature, using an inductive approach we discovered a variety of practices that teachers implemented to support immigrant students. In addition, inductive analyses led us to conclude that parental inclusion can be used as a component of the three categories of practices examined: academic support, language support, and promotion of a positive climate in the classroom. Finally, because the Tatar language is closely related to languages of other Turkic peoples, our study points to advantages of using it in Tatarstan to support teaching Russian as a foreign language.

\section{Limitations}

While use of qualitative methodology allowed us to discover teaching practices with immigrant children in Tatarstan, a limitation of the study is that it relied on the authors' interpretation of teachers' subjective reports regarding their teaching and issues that immigrant children face in the classroom. Although the interviews were valuable in understanding the teachers' experience, thoughts, and feelings from their perspective, this line of research can be complemented by observational studies of teachers' practice. Further, only quantitative research can document how frequently the teachers use the kinds of supporting strategies and teaching practices when working with immigrant children in Russia and Tatarstan. In addition, most teachers who took part in the study were female. This is due to the fact that the teaching profession is still predominantly female in Russia. Finally, teacher practices reflect beliefs and ideologies about educating diverse 
students. The question of how multicultural education is conceptualized in Russia, and whether foreign concepts of multiculturalism, interculturalism, or polyculturalism apply was beyond the scope of the present study but is important to investigate in future research.

Author Contributions: Conceptualization, C.G.; Investigation, R.K.; Methodology, D.B.; Project administration, A.K. All authors have read and agreed to the published version of the manuscript.

Funding: This research received no external funding.

Institutional Review Board Statement: The study was conducted accordance with guidelines of Helsinki declaration and regulations of Kazan Federal University for minimal risk research.

Informed Consent Statement: Informed consent was obtained from all subjects involved in the study.

Data Availability Statement: Not applicable.

Acknowledgments: This paper has been supported by the Kazan Federal Strategic Academic Leadership program.

Conflicts of Interest: The authors declare no conflict of interest.

Disclosure Statement: No potential conflict of interest was reported by the author.

\section{References}

1. Alexandrov, D.A.; Ivanyushina, V.A.; Kostenko, V.V.; Savelieva, S.S.; Tenisheva, K.A. The State of Immigrant Children in St. Petersburg; UNICEF: Moscow, Russia, 2012; pp. 24-30.

2. Zborovsky, G.E.; Shuklina, E.A. Обучение детей мигрантов как проблема их социальной адаптации [Training of migrant children as problem of their social adaptation]. Sociol. Res. 2013, 2, 80-91.

3. United Nations. International Migration Report 2017. 2017. Available online: https://www.un.org/en/development/desa/ population/migration/publications/migrationreport/docs/MigrationReport2017_Highlights.pdf (accessed on 9 January 2017).

4. Ministry of Internal Affairs of Russian Federation. Statistical information on migration situation. 2018. Available online: https:/ / xn--b1aew.xn--1ai/Deljatelnost/statistics/migracionnaya/item/14852910 (accessed on 19 October 2018).

5. Dudko, S.A. К вопросу об обучении детей мигрантов в России. [On the issue of teaching the immigrant children in Russia]. Values Mean. 2014, 3, 56-61.

6. The Federal Law on Education $N^{\circ}$ 273. 2013. Available online: http:/ / zakon-ob-obrazovanii.ru (accessed on 29 October 2013).

7. Zhukova, I.А. О үициальный статус детей мигрантов в Российской Федерации [The legal status of immigrant children in Russian Federation]. Russia. XXI Century 2015, 2, 38-40.

8. Gukalenko, O.V. Теоретико-методологические основы педагогической поддержки детей мигрантов в поликультурнойобра зовательной среде. [Theoretic-Methodological Basics of Pedagogical Support and Defense of Immigrant Students in Policultural Educational Environment]; Rosmen: Rostov-on-Don, Russia, 2000.

9. Polat, S.; Barka, T.O. Multiculturalism and Intercultural Education: A Comparative Study with a Sample of Swiss and Turkish Candidate Teachers. World Appl. Sci. J. 2012, 18, 1180-1189. [CrossRef]

10. Portera, A. Intercultural and Multicultural Education: Epistemological and Semantic Aspects. In Intercultural and Multicultural Education: Enhancing Global Interconnectedness; Grant, C.A., Portera, A., Eds.; Routledge: New York, NY, USA, 2010 ; pp. 12-30.

11. Holm, G.; Zilliacus, H. Multicultural education and intercultural education: Is there a difference? In Dialogs on Diversity and Global Education; Talib, M., Loima, J., Paavola, H., Patrikainen, S., Eds.; Peter Lang: Berlin, Germany, 2009; pp. 11-28.

12. Gorski, P. Complicity with conservatism: The de-politicizing of multicultural and intercultural education. Intercult. Educ. 2006, 17, 163-177. [CrossRef]

13. Valeeva, R.; Valeeva, A. Intercultural education from Russian researches perspective. Procedia Soc. Behav. Sci. 2017, $237,1564-1571$. [CrossRef]

14. Janta, B.; Harte, E. Education of Migrant Children: Education Policy Responses for the Inclusion of Migrant Children in Europe. Research Report. RAND Europe. 2016. Available online: https:/ /www.rand.org/content/dam/rand/pubs/research_reports/ RR1600/RR1655/RAND_RR1655.pdf (accessed on 12 October 2017).

15. Richards, H.V.; Brown, A.F.; Forde, T.B. Addressing diversity in schools: Culturally responsive pedagogy. Teach. Except. Child. 2007, 39, 64-68. [CrossRef]

16. Sclafani, C. Strategies for Educators of Bilingual Students: A Critical Review of Literature. Int. J. Educ. Lit. Stud. 2017, 5, 1-8. [CrossRef]

17. Khairutdinova, R.; Birman, D.; Kalimullin, A.; Gromova, C.; Semenova, E.; Troska, Z. Attitudes towards Cultural Diversity: A Study of Russian Teachers. J. Study Relig. Ideol. 2019, 18, 80-95.

18. Schachner, M.; van de Vijver, F.; Noack, P. Contextual conditions for acculturation and school-related outcomes of adolescent immigrants-Integrating y and findings. Online Read. Psychol. Cult. 2017, 8. [CrossRef] 
19. Vedder, P.H.; Horenczyk, G. Acculturation and the school. In The Cambridge Handbook of Acculturation Psychology; Sam, D.L., Berry, J.W., Eds.; Cambridge University Press: Cambridge, UK, 2006; pp. 419-438. [CrossRef]

20. Herrera, J.C. Teacher Beliefs and Practices: Their Effects on Student Achievement in the Urban School Setting. Doctoral Dissertation, Kansas State University, Kansas, MO, USA, 2010. Available online: http://krex.k-tate.edu/dspace/bitstream/ handle/2097/3889/JohnHerrera2010.pdf?sequence=7 (accessed on 23 May 2011).

21. Birman, D. Refugee Mental Health in the Classroom: A Guide for the ESL Teacher. Denver: Institute for Intercultural Learning. Available online: http:/ / www.spring-institute.org (accessed on 28 February 2013).

22. Gromova, C.; Khairutdinova, R.; Birman, D.; Kalimullin, A. Teaching technologies for immigrant children: An exploratory study of elementary school teachers in Russia. In Acculturation and School Adjustment of Minority Students: School and Family-Related Factors; Makarova, E., Ed.; Routledge: London, UK; Taylor \& Francis Group: London, UK, 2020; pp. 51-65.

23. Makarova, E.; Gilde, J.; Birman, D. Teachers as risk and resource factors of minority students' school adjustment: An integrative review of qualitative research on acculturation. Intercult. Educ. 2019, 30, 448-477. [CrossRef]

24. Raviv, A.; Keinan, G.; Abazon, Y.; Raviv, A. Moving as a stressful life event for adolescents. J. Community Psychol. 1990, 18, 130-140. [CrossRef]

25. Vedder, P.; Boekaerts, M.; Seegers, G. Perceived social support and wellbeing in school: The role of students' ethnicity. J. Youth Adolesc. 2005, 34, 269-278. [CrossRef]

26. Biasutti, M.; Concina, E.; Frate, S. Working in the classroom with migrant and refugee students: The practices and needs of Italian primary and middle school teachers. Pedagog. Cult. Soc. 2020, 28, 113-129. [CrossRef]

27. Dumcius, R.; Nicaise, I.; Balcaite, I.; Huttova, J.; Siarova, H. Study on Educational Support for Newly Arrived Migrant Children; European Commission: Brussels, Belgium, 2012. Available online: https://limo.libis.be/primo-explore/fulldisplay?docid= LIRIAS1897394andcontext=Landvid=Liriasandsearch_scope=Liriasandtab=default_tabandlang=en_US (accessed on 10 April 2015).

28. Christensen, G.; Stanat, P. Language policies and practices for helping immigrants and second-generation students succeed. In The Transatlantic Taskforce on Immigration and Integration; Migration Policy Institute (MPI) and Bertelsmann Stiftung: Gütersloh, Germany, 2007; pp. 1-15. Available online: https://www.naldic.org.uk/Resources/NALDIC/Research\%20and\%20Information/ Documents/ChristensenEducation091907.pdf (accessed on 21 September 2007).

29. Canagarajah, A. Translingual Practice: Global Englishes and Cosmopolitan Relations; Dworin, M., Milto, S., Eds.; Park, Routledge: Abingdon, UK, 2013; p. 445.

30. García, O.; Woodley, H.H.; Flores, N.; Chu, H. Latino Emergent Bilingual Youth in High Schools: Transcaring Strategies for Academic Success. Urban Educ. 2016, 48, 798-827. [CrossRef]

31. Ferlis, E.; $\mathrm{Xu}, \mathrm{Y}$. Prereferral process with Latino English language learners with specific learning disabilities: Perceptions of English-as-a-second-language teachers. Int. J. Multicult. Educ. 2016, 18, 22-39. [CrossRef]

32. Gibbons, P. Scaffolding language, scaffolding learning. In Teaching English Language Learners in the Mainstream Classroom, 2nd ed.; Heinemann Portsmouth: Portsmouth, NH, USA, 2015. Available online: https://assets.pearsonschool.com/asset_mgr/current/ 201511/gibbonschapter.pdf (accessed on 13 March 2017).

33. Levine, L.N.; Smallwood, B.A.; Haynes, E.F. Listening and Speaking: Oral Language and Vocabulary Development for English Language Learners. Hot Topics in ELL Education; Center for Applied Linguistics: Washington, DC, USA, 2012.

34. Herrell, A.L.; Jordan, M. 50 Strategies for Teaching English Language Learners, 5th ed.; Pearson: Boston, MA, USA, 2016.

35. Kudryavtseva, E.L.; Volkova, T.V.; Yakimovich, E.A. Обучение русскому языку в билингвальнойсреде. Рекомендации[Теасhіng Russian in the bilingual environment. Recommendations]; CSOT: Moscow, Russia, 2013.

36. Zheleznyakova, Е.А. Дети мигрантов всовременнойроссийской школе: Пути языковойадаптации[Children of migrants at modern Russian school: Ways of language adaptation]. News Penza State Pedagog. Univ. 2012, 28, 774-778.

37. Moskal, M. Language and cultural capital in school experience of Polish children in Scotland. Race Ethn. Educ. 2016, 19, 141-160. [CrossRef]

38. Birman, D.; Tran, N. The Academic Engagement of Newly Arriving Somali Bantu Students in a US Elementary School; Migration Policy Institute: Washington, DC, USA, 2015. Available online: https://sites.education.miami.edu/refugeecollab/publications/ (accessed on 19 January 2015).

39. Gay, G. Culturally responsive teaching in special education for ethnically diverse students: Setting the stage. Int. J. Qual. Stud. Educ. 2002, 15, 613-629. [CrossRef]

40. Graneheim, U.H.; Lundman, B. Qualitative content analysis in nursing research: Concepts, procedures and measures to achieve trustworthiness. Nurse Educ. Today 2004, 24, 105-112. [CrossRef]

41. Vygotsky, L.S. Main Psychological Proceedings: Thinking and Speech: The Problem of Child's Psychological Development; APN RSFSR: Moscow, Russia, 1956.

42. Gorski, P.C. What we're teaching teachers: An analysis of multicultural teacher education coursework syllabi. Teach. Teach. Educ. 2009, 25, 309-318. [CrossRef]

43. Civitillo, S.; Schachner, M.; Juang, L.; van de Vijver, F.J.; Handrick, A.; Noack, P. Towards a better understanding of cultural diversity approaches at school: A multi-informant and mixed-methods study. Learn. Cult. Soc. Interact. 2017, 12, 1-14. [CrossRef]

44. Alismail, H.A. Multicultural Education: Teachers' Perceptions and Preparation. J. Educ. Pract. 2016, 11, $139-146$. 
45. Sinkkonen, H.M.; Kyttälä, M. Experiences of Finnish teachers working with immigrant students. Eur. J. Spec. Needs Educ. 2014, 29, 167-183. [CrossRef]

46. Creswell, J.W. Qualitative Inquiry and Research Design: Choosing among Five Approaches; Sage Publications: Thousand Oaks, CA, USA, 2013.

47. Hsieh, H.F.; Shannon, S.E. Three approaches to qualitative content analysis. Qual. Health Res. 2005, 15, 1277-1288. [CrossRef] [PubMed]

48. Gorpas, R.; Triandafylliou, A. Greek education policy and the challenge of migration: An 'intercultural' view of assimilation. Race Ethn. Educ. 2011, 14, 399-419. [CrossRef]

49. Kalenkova, O.N. УрокиРусскойРечи[Russian Language Lessons]; Etnosfera: Moscow, Russia, 2007.

50. Levine, L.N.; Lukens, L.; Smallwood, B.A. The GO TO strategies: Scaffolding options for teachers of English language. 2013. Available online: https:// / / www.cal.org/ excell (accessed on 10 July 2017).

51. Sineva, O.V.; Sineva, V.S.; Kakorina, E.V. Русский язык вразноуровневом поликультурном классе: технологии языковойадаптации. Книга дляучителя[Russian language in multilevel policultural class: Technologies of Linguistic Adaptation. Book for Teacher]; Gaou Vo Mioo: Moscow, Russia, 2016.

52. Brown, K.E.; Medway, F.J. School climate and teacher beliefs in a school effectively serving poor South Carolina (USA) African American students: A case study. Teach. Teach. Educ. 2007, 23, 529-540. [CrossRef]

53. Diamond, J.B.; Randolph, A.; Spillane, J.P. Teachers' expectations and sense of responsibility for student learning: The importance of race, class, and organizational habitus. Anthropol. Educ. Q. 2004, 35, 75-98. [CrossRef]

54. Heckman, F. Education and Migration: Strategies for Integrating Migrant Children in European schools and Societies. Available online: http:/ / www.nesse.fr/nesse/activities/reports (accessed on 12 April 2008).

55. Banks, J.A. Multicultural Education: Historical Development, Dimensions, and Practice. In Handbook of Research on Multicultural Education; Banks, J.A., Banks, C.A.M., Eds.; Jossey-Bass: San Francisco, CA, USA, 2004; pp. 3-29.

56. Kagan, S.; Kagan, S. Cooperative Learning; Narayana Press: Odder, Denmark, 2008; Volume 2.

57. Karuppiah, N.; Berthelsen, D. Multicultural education: The understandings of preschool teachers in Singapore. Australas. J. Early Child. 2011, 36, 38-42. [CrossRef]

58. Robles de Melendez, W.; Ostertag, V. Critical Multiculturalism: Rethinking Multicultural and Antiracist Education; Delmar Publishers: Boston, MA, USA, 1997.

59. Derman-Sparks, L.; Force, A.B. Anti-Bias Curriculum Tools for Empowering Young Children; 1834 Connecticut Avenue; National Association for the Education of Young Children: Washington, DC, USA, 1989.

60. Belyankova, N.M. Некоторые формыорганизации внеурочных мероприятий в классах смешанного этнического состава. [Some organization forms of the events done in addition to class hours in classes of the mixed ethnic structure]. Elem. Sch. 2014, 6, 94-95.

61. Ilyinskaya, I.P. Воспитание в поликультурнойсреде средствами народных сказок. [Education of elementary school pupils in the polycultural environment]. Elem. Sch. 2008, 5, 14-15.

62. Lebedeva, N.M.; Tatarko, A.N. Стратегии межкультурного взаимодействия мигрантов и населенияPоссии[Strategies for Intercultural Interaction of Migrants and the Population of Russia]; RUDN: Moscow, Russia, 2009.

63. Makarova, E.; Döring, A.K.; Auer, P.; t'Gilde, J.; Birman, D. School adjustment of ethnic minority youth: A qualitative and quantitative research synthesis of family-related risk and resource factors. Educ. Rev. 2021. [CrossRef]

64. Grant, C.A.; Gillette, M. A candid talk to teacher educators about effectively preparing teachers who can teach everyone's children. J. Teach. Educ. 2006, 57, 292-299. [CrossRef] 